\title{
Wastewater Purification from Permanganate Ions by Sorption on the Ocimum basilicum Leaves Powder Modified by Zinc Chloride
}

\author{
Nasser A. Alamrani $\mathbb{D}^{1},{ }^{1}$ Hatem A. Al-Aoh $\mathbb{D}^{1}{ }^{1}$ Meshari M. H. Aljohani ${ }^{1}{ }^{1}$ \\ Suhair A. Bani-Atta $\mathbb{D}^{1}{ }^{1}$ M. Sobhi $\mathbb{D}^{1,2}$ Mustafa Syed Khalid $\mathbb{D}^{1},{ }^{1}$ A. A. A. Darwish $\mathbb{D}^{3,4}$ \\ Ali A. Keshk $\mathbb{D}^{1}{ }^{1}$ and Mona A. A. Abdelfattah $\mathbb{D}^{5}$ \\ ${ }^{1}$ Department of Chemistry, Faculty of Science, University of Tabuk, Tabuk 71491, Saudi Arabia \\ ${ }^{2}$ Department of Chemistry, Faculty of Science, Benha University, Benha, Egypt \\ ${ }^{3}$ Department of Physics, Faculty of Education at Al-Mahweet, Sana'a University, Al-Mahweet, Yemen \\ ${ }^{4}$ Department of Physics and Nanotechnology Research Unit, Faculty of Science, University of Tabuk, Tabuk 71491, Saudi Arabia \\ ${ }^{5}$ Department of Civil Engineering, Higher Institute for Engineering \&Technology, Giza, Egypt
}

Correspondence should be addressed to Suhair A. Bani-Atta; s_bantatta@ut.edu.sa

Received 8 February 2021; Revised 16 June 2021; Accepted 10 July 2021; Published 22 July 2021

Academic Editor: Mallikarjuna N. Nadagouda

Copyright (c) 2021 Nasser A. Alamrani et al. This is an open access article distributed under the Creative Commons Attribution License, which permits unrestricted use, distribution, and reproduction in any medium, provided the original work is properly cited.

\begin{abstract}
The powder of Ocimum Basilicum leaves was treated by zinc chloride $\left(\mathrm{ZnCl}_{2}\right)$ and applied as a new and low-cost sorbent for extraction of permanganate anions $\left(\mathrm{MnO}_{4}{ }^{-}\right)$from liquid phase. The functional groups of the ring stretching vibration, $-\mathrm{NH}_{2}$ deformation, stretching of $\mathrm{C}-\mathrm{O}$, stretching of $\mathrm{CH}$, and stretching of $-\mathrm{NH}$ were found in the sorbent of zinc chloride Ocimum basilicum leaves powder (ZCOBLP) at 1516.21, 1629.33, 1047.00, 2929.88, and $3294.93 \mathrm{~cm}^{-1}$, respectively. This adsorbent has 8.3 $\mathrm{pHZPC}, 117.27 \mathrm{~m}^{2} \cdot \mathrm{g}^{-1}$ surface area, $0.00711 \mathrm{cc} \cdot \mathrm{g}^{-1}$ pore volume and average pore diameter of $264.144 \AA$. The outcomes of sorption experiments designate the positive impact for temperature, time of agitation, and started concentration of $\mathrm{MnO}_{4}{ }^{-}$and negative impact for $\mathrm{pH}$. The optimal conditions were $1300 \mathrm{mg} \cdot \mathrm{L}^{-1}$ as started adsorbate concentration, $55^{\circ} \mathrm{C}$ as solution temperature, agitation time of $420 \mathrm{~min}$, and $\mathrm{pH}$ of 1.5. The outcomes of the equilibrium and dynamic approve that this sorption is spontaneous and heat-absorbing process, and the obtained data were described well by isotherm model of Langmuir and 2nd-order dynamic model. The capacities of this sorption were $588.235,625.000,666.667$, and $714.286 \mathrm{mg}^{\circ} \mathrm{g}^{-1}$ at $25,35,45$, and $55\left({ }^{\circ} \mathrm{C}\right)$, respectively. The superior sorption capacities of the uncostly ZCOBLP will make it successfully used for $\mathrm{MnO}_{4}{ }^{-}$ions extraction from liquid phases.
\end{abstract}

\section{Introduction}

Potassium permanganate $\left(\mathrm{KMnO}_{4}\right)$ is broadly used for a large number of applications; it is largely applied as a very strong oxidizing agent in laboratories and chemical industries. $\mathrm{KMnO}_{4}$ is used for medical purposes, especially skin conditions [1]. The List of World Health Organizations of Essential Medicines considered potassium permanganate as one of the harmless and most active medicines in the health system [2]. It is also widely used in water treatment to remove chemical elements and compounds that cause unwanted color and odor like iron and hydrogen sulfide gas [3-5]; its primary function was to oxidize colors, cyanide, and phenols [6-10], and currently it is used to stop the growth of some organisms in the water [11].

According to the National Institute of Occupational Safety and Health (NIOSH) report, $\mathrm{KMnO}_{4}$ was classified recently as a hazardous and harmful substance to human health. Direct exposure to permanganate causes shortness of breath, burns to the skin, and pain in the eyes; it may also 
cause some damage to the nervous system as it causes shock and nervous collapse [12], while continuous exposure to it causes long-term toxic effects.

To remove potassium permanganate from water before it is released as wastewater, several technologies and techniques such as biological degradation, ion exchange, membrane separation, oxidation by chemical agents, and sorption have been developed and implemented [11, 13]. Sorption is one of the most widely utilized techniques due to its simplicity, high sorption capacity, environmental friendliness, nontoxicity, and availability of a large range of sorbents [11].

Activated carbon is widely used as a sorbent for water purification from $\mathrm{KMnO}_{4}$ [14]; for instance, coconut shells, corncob, and bone have been used to synthesize activated carbon and applied for $\mathrm{KMnO}_{4}$ sorption from aqueous solutions $[14,15]$. Charcoal and activated carbon were modified by $\mathrm{H}_{2} \mathrm{SO}_{4}$ and used for removing of $\mathrm{KMnO}_{4}$ from wastewater $[11,16]$. In spite of the impressive effectiveness of activated carbon, the cost of preparing is very high. Other materials like metallic oxides nanoparticles (NPS) have been used as sorbents for purification wastewater from different dyes [17-23]. On the other hand, many researchers have used cheap and available materials in their areas as sorbents to get rid of water-pollution dyes. For instance, sugar beet pulp [24], seed shells [25], powder of mango leaf [26], the shell of cashew nut [27], the substrate of spent mushroom [28], natural clay [29], powder calcined of corncob [30], and powder of neem leaves [31] were applied to remove different dyes from wastewater. Lately, the modified leaves powders of Nitraria retusa, neem, and sage plants have been used for $\mathrm{KMnO}_{4}$ removal from aqueous samples [32, 33].

The Ocimum basilicum plants present in various geographical areas, sometimes called Reyhan or Habag, the leaves of these plants distinguished in a distinctive aromatic scent without any toxic properties. Its unique smell and lack of any toxicity enabled many peoples to use it as a flavoring for food and tea. In ancient times, its leaves were also used in folk medicine for many symptoms like skin infection and colic ulcer [34]. Recently, powder of its seeds was applied for removing of heavy metals from water [35-37]. Moreover, Ocimum basilicum has been practical in order to remove the Congo red dye from water [38]. Up to now, there is no study of the use of Ocimum basilicum leaves as a low-cost sorbent for permanganate removal. Therefore, the present work aims to manufacture a new sorbent from leaves of the Ocimum basilicum and to investigate its removal ability of $\mathrm{KMnO}_{4}$ from aqueous medias. Parameters of thermodynamics, isotherms, and kinetics will be also investigated, as the factors that impact the performance of $\mathrm{KMnO}_{4}$ sorption by this sorbent will also be inspected.

\section{Methodology}

2.1. Sorbent Modification. The Ocimum basilicum plants were brought from the local market, and the leaves were separated and isolated from the rest of the plant. The leaves were cleaned with distilled water before being air-dried for two weeks. Using a manual milling equipment, the dried leaves were ground into a powdery state and sieved to a mesh size of 0.5 to $2 \mathrm{~mm}$. A $150 \mathrm{~g}$ of the resulting powder was reflexed in $2500 \mathrm{~mL}$ a round-bottom flask with $1000 \mathrm{~mL}$ of $\mathrm{ZnCl}_{2}$ solution $(30 \% \mathrm{w} / \mathrm{w})$ at a boiling point for $120 \mathrm{~min}$, followed by cooling at room temperature and filtration. The remaining solid was boiled with $500 \mathrm{~mL} \mathrm{HCl}(0.1 \mathrm{M})$ for 40 min to remove $\mathrm{ZnCl}_{2}$ from the sample; then, the solid sample was obtained by filtration, and to make sure that the sample does not contain any $\mathrm{HCl}$ acid, the solid sample was washed repeatedly by distilled water and oven-dried at $130^{\circ} \mathrm{C}$ for $30 \mathrm{~h}$. Finally, the obtained powder was stored for sorption processes.

2.2. Characterization of Sorbent. Fourier transform infrared (FTIR) spectroscopy (Nicolet iS5 of Thermo Scientific FTIR) was used to characterize the zinc chloride Ocimum basilicum leaves powder (ZCOBLP) sorbent. The measurements were carried out between 4000 and $400 \mathrm{~cm}^{-1}$ in order to identify sorbent functional groups that could be useful in the sorption of permanganate from wastewater. The morphology of ZCOBLP before and after sorption also was recognized by using Microscopy of Scanning Electron (SEM), whereas the surface area and porosity of the synthesized sorbent were measured using the surface analyzer technique (NOVA-2200 Ver. 6.11). The $\mathrm{pH}$ of solution at which the ZCOBLP surface is uncharged $\left(\mathrm{pH}_{\mathrm{ZPC}}\right)$ was estimated according to Theydan and Ahmed's method [25], where three $500 \mathrm{~mL}$ solutions of $0.1 \mathrm{M}, 0.01 \mathrm{M}$, and $0.001 \mathrm{M}$ $\mathrm{NaNO}_{3}$ have been prepared, as well as a series of six $50 \mathrm{~mL}$ solutions with varied $\mathrm{pH}$ values ranging from 1 to 11 for each of these three solutions, using $0.1 \mathrm{M} \mathrm{HCl}$ or $\mathrm{NaOH}$ solutions. In $100 \mathrm{~mL}$ glass bottles, each of these solutions was combined with $0.1 \mathrm{~g}$ of ZCOBLP. These bottles were shaken for $20 \mathrm{~h}$ at room temperature $\left(25^{\circ} \mathrm{C}\right)$ and $140 \mathrm{rpm}$ in shaker incubator. The differences between the start and final $\mathrm{pH}$ values $\left(\mathrm{pH}_{\mathrm{i}}-\mathrm{pH}_{\mathrm{f}}\right)$ were calculated and plotted against $\mathrm{pH}_{\mathrm{i}}$ to estimate the $\mathrm{pH}_{\mathrm{ZPC}}$ value of the sorbent utilized in this study.

\subsection{Impact of Experimental Conditions}

2.3.1. Contact Time Impact. To determine the sorption equilibrium time and investigate the effect of agitation time, $0.03 \mathrm{~g}$ of ZCOBLP was shaked with $15 \mathrm{~mL}$ of 200,300 , and $400 \mathrm{mg} \cdot \mathrm{L}^{-1}$ of $\mathrm{KMnO}_{4}$ solutions at various times $(5,15,30$, $45,90,180,300,420,600,840$, and $960 \mathrm{~min}), 25^{\circ} \mathrm{C}, 140 \mathrm{rpm}$, and initial solution $\mathrm{pH}$ conditions. The remaining $\mathrm{KMnO}_{4}$ concentrations in the filtrate was identified by UV/visible spectrometer at $\lambda=525 \mathrm{~nm}$. The following equation was used for computing the sorption quantities $\left(q_{t}\right)$ :

$$
q_{t}=\frac{V\left(C_{0}-C_{t}\right)}{m} .
$$

A $q_{t}\left(\mathrm{mg} \cdot \mathrm{g}^{-1}\right)$ belongs to the adsorbed quantity of $\mathrm{KMnO}_{4}$ at any time. $V$ and $m$ are the volume solution and ZCOBLP mass. $C_{0}$ and $C_{t}$ are $\mathrm{KMnO}_{4}$ concentrations at initial and time $t$, correspondingly. 
2.3.2. Impact of $p H$. To examine the influence of $\mathrm{pH}$ solution on $\mathrm{KMnO}_{4}$, sorption by ZCOBLP from aqueous solutions batch sorption experiment was done. $15 \mathrm{~mL}$ of $700 \mathrm{mg} \cdot \mathrm{L}^{-1}$ $\mathrm{KMnO}_{4}$ at different $\mathrm{pH}$ values ranged from 1.5 to 11 was added to six amber flasks containing $0.03 \mathrm{~g}$ of ZCOBLP absorbent. Solutions of each $0.1 \mathrm{M} \mathrm{NaOH}$ or $0.1 \mathrm{M} \mathrm{HCl}$ were used to adjust of $\mathrm{pH}$ values. Automatic shaker was used for shaking the six bottles for $20 \mathrm{~h}$ at $25^{\circ} \mathrm{C}$ and $140 \mathrm{rpm}$. For each sample, the filtration process was done followed by determining the remaining concentration of $\mathrm{KMnO}_{4}$ using a 6800 UV-visible spectrophotometer (Jenway) at $\lambda_{\max }$ $525 \mathrm{~nm}$. The following equation was applied to determine the sorption amounts by ZCOBLP at equilibrium:

$$
q_{e}=\frac{\left(C_{0}-C_{e}\right) V}{m}
$$

where $q_{e}\left(\mathrm{mg}^{-1} \mathrm{~g}^{-1}\right)$ is the quantity of sorption by ZCOBLP at equilibrium, $C_{0}$ is the $\mathrm{KMnO}_{4}$ concentration, $C_{e}$ is the $\mathrm{KMnO}_{4}$ equilibrium concentration, $V$ is the $\mathrm{KMnO}_{4}$ solution volume (L), and $m$ is the mass of ZCOBLP (g).

2.3.3. Temperature and Concentration Effects. To investigate the effects of temperature and primary $\mathrm{KMnO}_{4}$ concentration on ZCOBLP sorption, $15 \mathrm{~mL}$ of different concentrations (200-1500 mg. $\mathrm{L}^{-1}$ ) of $\mathrm{KMnO}_{4}$ solutions was mixed with $0.03 \mathrm{~g}$ of the ZCOBLP in $30 \mathrm{~mL}$ amber bottles, followed by shaking of each mixture for $20 \mathrm{~h}$ at $25,35,45$, and $55^{\circ} \mathrm{C}$ temperatures and $140 \mathrm{rpm}$, followed by filtration and UVvisible measurements. The sorption amounts $\left(q_{e}\right)$ of $\mathrm{KMnO}_{4}$ by ZCOBLP sorbent were assessed using equation (2). Finally, the $q_{e}$ values were schemed versus $C_{0}\left(\mathrm{mg}^{-1} \mathrm{~g}^{-1}\right)$ for each temperature.

2.4. Equilibrium Experiments. The experimental data of Section 2.3.3 were examined by the Langmuir, Freundlich, and Temkin models represented by equations (3)-(6), oneto-one:

$$
\begin{aligned}
\frac{C_{e}}{q_{e}} & =\frac{1}{q_{\max } K_{L}}+\frac{C_{e}}{q_{\max }}, \\
R_{L} & =\frac{1}{1+K_{L} C_{0}}, \\
\ln q_{e} & =\ln K_{F}+\frac{1}{n} \ln C_{e}, \\
q_{e} & =B_{1} \ln K_{T}+B_{1} \ln C_{e},
\end{aligned}
$$

$q_{\max }$ is $\left(\mathrm{mg} \cdot \mathrm{g}^{-1}\right)$ the maximum sorption capacity, $R_{L}$ is the dimensionless factor, $K_{L}, K_{F}$, and $K_{T}$ are the constants of Langmuir, Freundlich, and Temkin, correspondingly. $N$ is the sorption intensity and $B_{1}$ is the constant correlated to sorption heat.

The parameters of thermodynamic like enthalpy, entropy, and free energy changes $\left(\Delta H^{\circ}, \Delta S^{\circ}\right.$, and $\left.\Delta G^{\circ}\right)$ of this sorption were assessed using the following equations, where
$R$ is the general gas constant $\left(0.008314 \mathrm{~kJ} \cdot \mathrm{K}^{-1} \cdot \mathrm{mol}^{-1}\right)$ and $T$ is the temperature $(\mathrm{K})$ :

$$
\begin{aligned}
\operatorname{Ln}\left(\frac{q_{e}}{C_{e}}\right) & =-\frac{\Delta H^{\circ}}{\mathrm{RT}}+\frac{\Delta S^{\circ}}{R}, \\
\Delta G^{\circ} & =\Delta \mathrm{H}^{\circ}-T \Delta S^{\circ} .
\end{aligned}
$$

2.5. Kinetic Experiments. In order to evaluate kinetic parameters of $\mathrm{KMnO}_{4}$ sorption by ZCOBLP, the obtained results from Section 2.3.2 were analyzed using 1st-order, 2nd-order, and intraparticle distribution models demonstrated in the following linear expressions:

$$
\begin{aligned}
\log \left(q_{e}-q_{t}\right) & =\log q_{e}-K_{1} \frac{t}{2.303}, \\
\frac{t}{q_{t}} & =\frac{1}{K_{2} q_{e}^{2}}+\frac{t}{q_{e}}, \\
q_{t} & =K_{\mathrm{dif}} \sqrt{t}+C,
\end{aligned}
$$

where $q_{e}$ and $q_{t}$ are the $\mathrm{KMnO}_{4}$ amount of sorption at equilibrium and the removed $\mathrm{KMnO}_{4}$ amount from solution after every interval of time, correspondingly. $C$ is a dynamic constant associated with the width of boundary layer. The constants of 1st-order, 2nd-order, and intraparticle distribution models are $K_{1}, K_{2}$, and $K_{\text {dif }}$, respectively.

\section{Results and Discussion}

3.1. Properties of $Z C O B L P$. The outcomes got from experiments of $\mathrm{pH}_{\mathrm{ZPC}}$ ( $\mathrm{pH}$ of the solution at which the net charge on the sorbent surface is zero) and sorbent surface analyzer are registered in Table 1. The obtained results approve that ZCOBLP has suitable surface area, pore volume, and pore diameter which have significant impacts on the sorption act of each sorbent.

The types of the functional groups present on the surface of ZCOBLP which play an imperative role in the sorption process were summarized with their absorption bands in Table 2. As can be seen in this table, the functional groups of the ring stretching vibration, $-\mathrm{NH}_{2}$ deformation, stretching of $\mathrm{C}-\mathrm{O}$, stretching of $\mathrm{CH}$, and stretching of $-\mathrm{NH}$, were found in the sorbent of ZCOBLP at 1516.21, 1629.33, 1047.00, 2929.88 , and $3294.93 \mathrm{~cm}^{-1}$, correspondingly. Moreover, there is no any peak related to stretching of $-\mathrm{Cl}$, which confirms that ZCOBLP become free from $\mathrm{Cl}$ ions $\left(\mathrm{Cl}^{-}\right)$after sample washing.

The ZCOBLP microstructures (spectrum of SEM) before and after sorption are illustrated in Figures 1(a) and 1(b), respectively. As shown in Figure 1, the sorption altered the surface roughness of the ZCOBLP significantly. Its surface was heterogeneous prior to sorption, indicating the presence of pores of various shapes and sizes. Nevertheless, after the sorption of $\mathrm{MnO}_{4}{ }^{-}$ions, a thick layer of adsorbate was seen covering the pores, giving the surface a smooth shape. 
TABLE 1: Results of $\mathrm{pH}_{\mathrm{ZPC}}$ and BET surface analyzer of the sorbent used in this work.

\begin{tabular}{lr}
\hline Properties & Obtained results \\
\hline $\mathrm{pH}$ & 8.3 \\
Surface area & $117.27 \mathrm{~m}^{2} \cdot \mathrm{g}^{-1}$ \\
Total pore volume & $0.00711 \mathrm{cc} / \mathrm{g}$ \\
Average pore diameter & $264.144 \AA$ \\
\hline
\end{tabular}

TABLE 2: The FT-IR spectrum's absorption bands and their functional groups.

\begin{tabular}{lc}
\hline Absorption band $\left(\mathrm{cm}^{-1}\right)$ & Functional group \\
\hline 1516.21 & Ring stretching vibration \\
1629.33 & $-\mathrm{NH}_{2}$ deformation \\
1047.00 & Stretching of C-O \\
2929.88 & Stretching of CH \\
3294.93 & Stretching of -NH \\
\hline
\end{tabular}

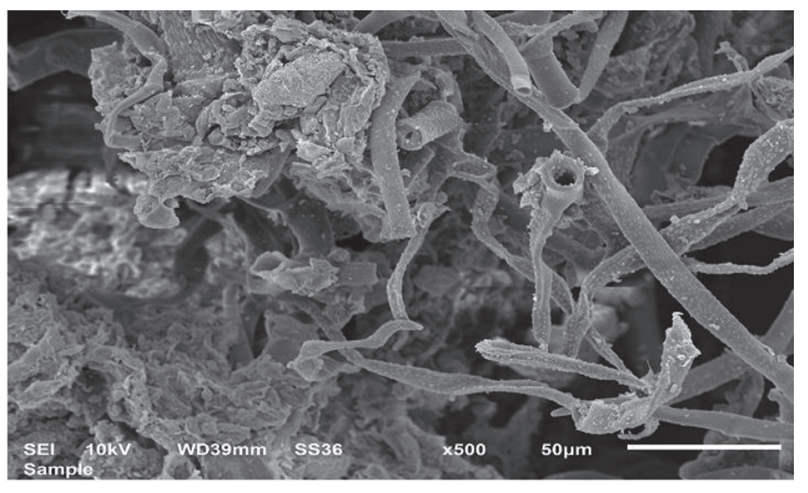

(a)

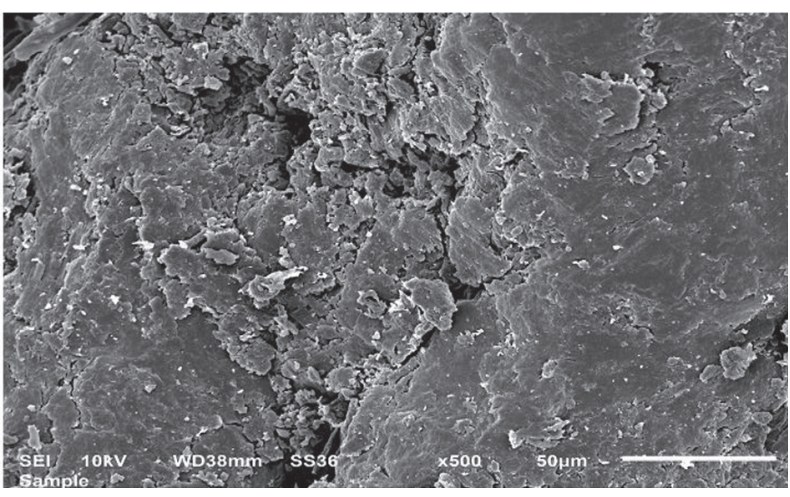

(b)

Figure 1: SEM spectrum of ZCOBLP (a) before and (b) after sorption.

\subsection{Impact of Experimental Conditions}

3.2.1. Impact of Contact Time. Sorption of $15 \mathrm{~mL}$ of 200,300 , and $400 \mathrm{mg} \cdot \mathrm{L}^{-1}$ of $\mathrm{KMnO}_{4}$ solution by $0.03 \mathrm{~g}$ of ZCOBLP performed at various times (5 to $960 \mathrm{~min}$ ), $25^{\circ} \mathrm{C}, 140 \mathrm{rpm}$, and initial solution $\mathrm{pH}$ to examine the effect of agitation time and to identify the equilibrium sorption time. The values of $q_{t}$ were calculated and plotted against contact time $(t)$ as revealed in Figure 2. As can be seen in Figure 2, the $q_{t}$ values for each concentration significantly increased in the range of (5-45 $\mathrm{min})$, indicating that the majority of sorption sites were empty at this time. Then, as the contact time increases in the range of 45-300 min, the values of $q_{t}$ steadily increased because the sorption sites began to be partially occupied by $\mathrm{MnO}_{4}{ }^{-}$ions. Moreover, there is not any change in the values of $q_{t}$ that can be observed (Figure 2) after $300 \mathrm{~min}$. The outcomes of this section agreed well with those reported for $\mathrm{MnO}_{4}{ }^{2-}$ sorption by Nitraria retusa [32].

3.2.2. Impact of $p H$. Figure 3 proves the results related to the effect of solution $\mathrm{pH}$ on sorption of $\mathrm{MnO}_{4}{ }^{-}$by ZCOBLP $\left(\mathrm{pH}_{\mathrm{ZPC}}=8.3\right)$. This figure indicates that $q_{e}$ of this sorption is slowly and suddenly decreased when $\mathrm{pH}$ values of $\mathrm{MnO}_{4}{ }^{2-}$ elevated from 1.5 to 7 and from 7 to 11 , respectively. The first decreasing was because of decreasing the attraction force between the negative ions of $\mathrm{MnO}_{4}{ }^{-}$and the positive charges present on the surface of ZCOBLP $\left(\mathrm{pH}<\mathrm{pH}_{\mathrm{ZPC}}\right.$ ), which are decreased when $\mathrm{pH}$ increased in the range of (1.5-7) [29], whereas the fast decreasing obtained in the values of $q_{e}$ at $\mathrm{pH}$ over 7 was as a result of the force of repulsion between the negatively charged ZCOBLP surface $\left(\mathrm{pH}>\mathrm{pH}_{\mathrm{ZPC}}\right)$ and anions of $\mathrm{MnO}_{4}^{-}$[29]. Similar outcomes were reported for $\mathrm{MnO}_{4}{ }^{-}$sorption by Nitraria retusa [32].

3.2.3. Temperature and Concentration Effects. The results of experiments associated with the impact of temperature and concentration of $\mathrm{MnO}_{4}{ }^{-}$solution on this sorption are represented in Figure 4. As illustrated in this figure, the amount of $\mathrm{MnO}_{4}{ }^{-}$adsorbed by ZCOBLP $\left(q_{e}\right)$ is increased when the adsorbate concentration elevated from 200 to $1300 \mathrm{mg} \cdot \mathrm{L}^{-1}$ and almost be invariable over $1300 \mathrm{mg} \cdot \mathrm{L}^{-1}$. Because when the adsorbate concentration was increased in the range of $200-1300 \mathrm{mg} \cdot \mathrm{L}^{-1}$, the mass transfer resistance between the aqueous solution of $\mathrm{MnO}_{4}{ }^{-}$and the solid surface of ZCOBLP was reduced, resulting in an increase in the values of $q_{e}$ [34], whereas there is not any vacant active site that will be available to adsorb extra ions of $\mathrm{MnO}_{4}{ }^{-}$when the adsorbate concentration increased over $1300 \mathrm{mg} \cdot \mathrm{L}^{-1}$. 


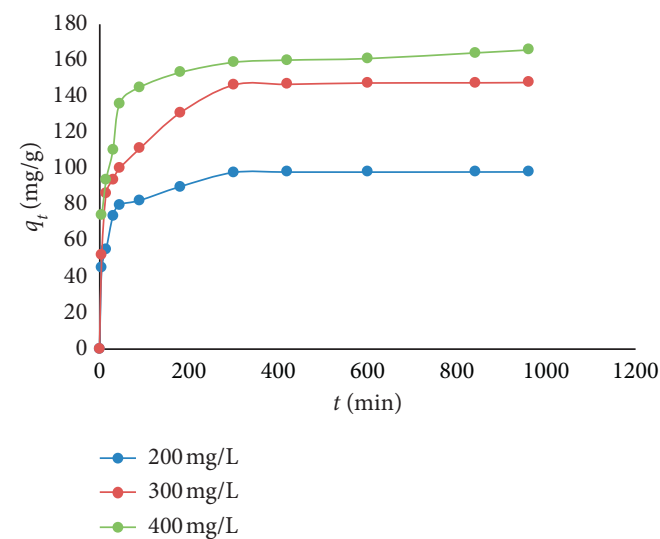

FIgURE 2: Impact of contact time on $\mathrm{MnO}_{4}{ }^{-}$ions sorption by ZCOBLP.

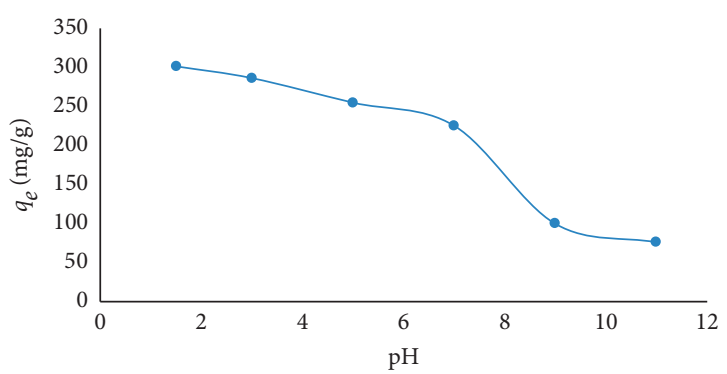

Figure 3: Effect of $\mathrm{pH}$ solution on $\mathrm{MnO}_{4}{ }^{-}$ions sorption by ZCOBLP.

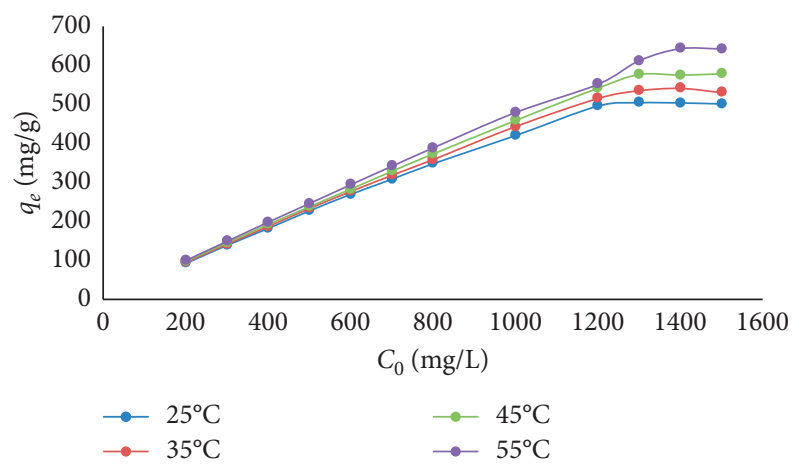

FIgURE 4: Effects of temperature and $\mathrm{MnO}_{4}{ }^{-}$concentration on sorption efficiency of ZCOBLP.

Therefore, $q_{e}$ be invariable after this concentration. Figure 4 also identifies that $q_{e}$ of this sorption is positively affected by temperature. Because the movement energy of $\mathrm{MnO}_{4}{ }^{-}$ions is increased and the solution viscosity is decreased by elevating temperature [39], these outcomes confirm that this sorption is an endothermic process. Similar thing was noted for $\mathrm{MnO}_{4}{ }^{-}$by neem leaves powder [33].

3.3. Dynamic Parameters. The dynamic models of 1st-order, 2nd-order, and intraparticle diffusion were used to analyze the experimental data from Section 2.3.1 in order to determine the kinetic parameters for $\mathrm{MnO}_{4}{ }^{-}$ions sorption by
ZCOBLP. The plots of these three dynamic models are depicted in Figures 5-7 for 1st-order, 2nd-order, and intraparticle diffusion, one-to-one.

The dynamic constants of this sorption were calculated from the slopes and intercepts of these plots (Figures 5-7) and recorded in Tables 3 and 4. According to these three figures, the best linear plots can be observed in Figure 5 . Moreover, in comparison between $R^{2}$ values of the 1st- and the 2 nd-order models (Table 3 ), $R^{2}$ values of 2 nd order are higher than those of 1st order. Furthermore, experimental values of $q_{e}\left(q_{e \cdot \exp }\right)$ are almost equal to the values of $q_{e}$ $\left(q_{e 2 . c a l}\right)$, which were calculated by applying the dynamic model of 2 nd order and differ from the values of $q_{e}\left(q_{e 1 . c a l}\right)$ obtained by using the first-order dynamic model. All of these observations strongly confirm that this sorption follows the 2nd-order dynamic model, which indicates that the $\mathrm{MnO}_{4}{ }^{-}$ ions are adsorbed on the surface of ZCOBLP by chemical bands.

The same outcomes were reported for sorption of $\mathrm{MnO}_{4}{ }^{-}$ions by activated carbon [15] and chemical modified sage leaves powder [40].

Figure 7 of intraparticle diffusion and values of $R^{2}$. Table 4 shows that the entire time range could not be fitted by a straight line, but it could be divided into two linear sections, implying that the sorption of $\mathrm{MnO}_{4}{ }^{-}$ion could be influenced by many processes. By increasing the adsorbate concentration, the values of parameter $C$ were increased from 44.782 to 69.870 in area 1 and from 97.732 to 150.030 in region 2, implying that the thickness of the boundary layer was positively affected by the concentration of $\mathrm{MnO}_{4}{ }^{-}$ions solution (Table 4). It is also worth noting that none of the plots in Figure 7 traveled through the origin, suggesting that intraparticle diffusion was not the only rate-limiting step and that some other process must have coexisted with intraparticle diffusion.

Very close results relating to intraparticle diffusion were obtained for sorption of $\mathrm{MnO}_{4}{ }^{-}$ions by chemical modified sage leaves powder sorbent [40].

3.4. Isotherm Parameters. The data of the experiments performed in Section 2.3.3 were also analyzed by models of Langmuir, Freundlich, and Temkin to determine the maximum sorption capacity and isotherm constant of this sorption. The plots of these models are shown in Figure 8 (Langmuir), Figure 9 (Freundlich), and Figure 10 (Temkin). The constants values of each isotherm model were computed from the slopes and intercepts of its plots and documented in Table 5.

The higher values of $R^{2}$ that were obtained by applying the model of Langmuir (Table 5) along with Figures 8-10 prove that the plots of Figure 8 (Langmuir) are more linear than those of the other two figures. This means that this sorption follows Langmuir model further than the other two models, confirming a monolayer sorption and homogeneity of the effective sites on the surface of ZCOBLP. The values of $R_{L}$ (ranged from 0.01616 to 0.07084 ) and $1 / n$ (ranged from 0.402 to 0.494 ) (Table 5) are less than unity, indicating the favorability of the experimental conditions applied in this 


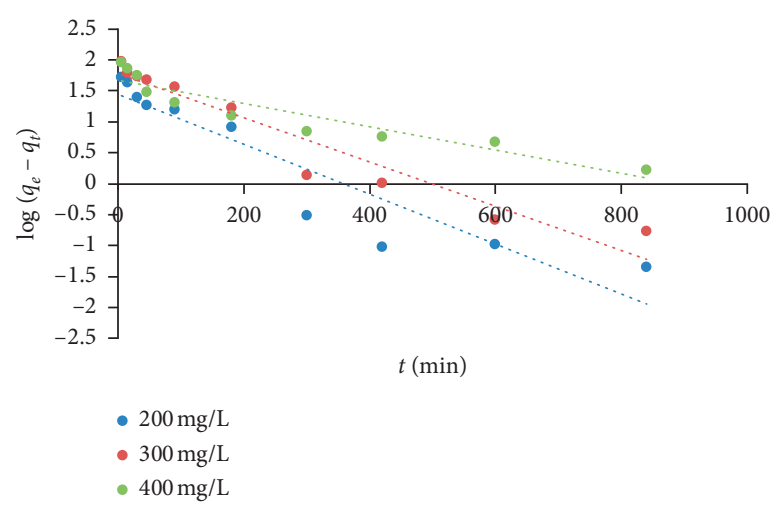

FIgure 5: The first-order dynamic model for $\mathrm{MnO}_{4}{ }^{-}$ions sorption by ZCOBLP.

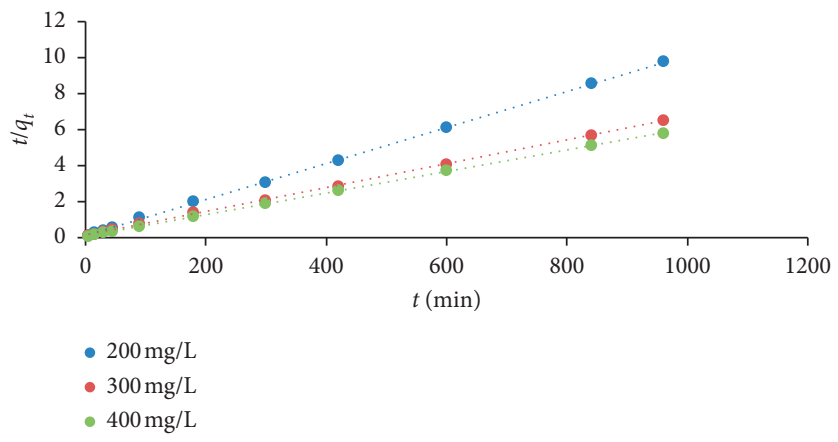

FIgure 6: The second-order dynamic model for $\mathrm{MnO}_{4}{ }^{-}$ions sorption by ZCOBLP.

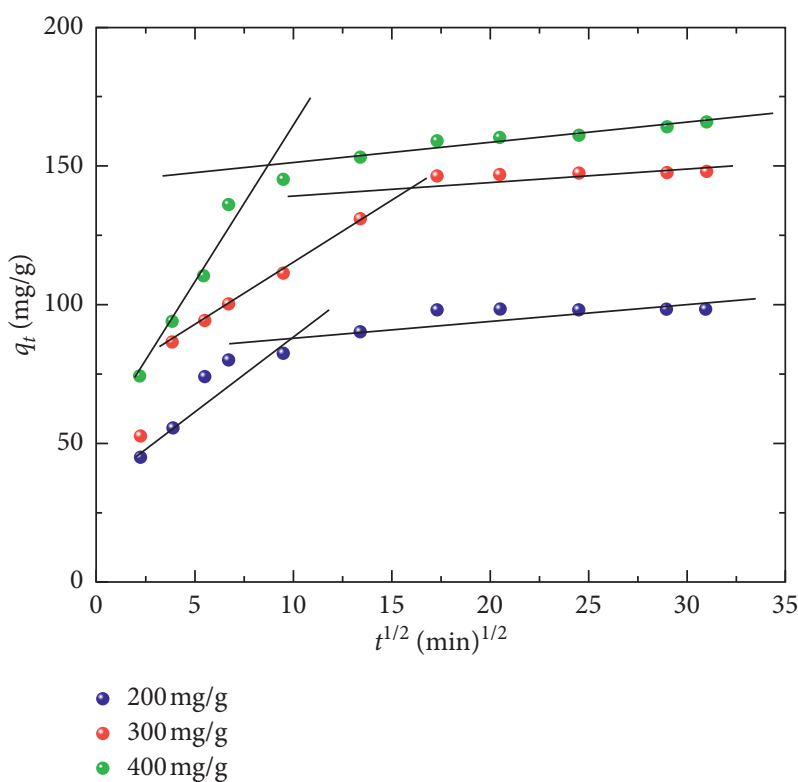

Figure 7: Intraparticle diffusion model for $\mathrm{MnO}_{4}{ }^{-}$ions sorption by ZCOBLP.

TABLE 3: Parameters of the 1st- and 2nd-order dynamic models for $\mathrm{MnO}_{4}{ }^{-}$sorption by ZCOBLP.

\begin{tabular}{lcccccccc}
\hline \multirow{2}{*}{$C_{0}(\mathrm{mg} / \mathrm{L})$} & \multirow{2}{*}{$q_{e, \text { exp }}(\mathrm{mg} / \mathrm{g})$} & \multicolumn{2}{c}{ Pseudo-first-order kinetic model } & \multicolumn{3}{c}{ Pseudo-second-order kinetic model } \\
& & $q_{e 1, \text { cal }}(\mathrm{mg} / \mathrm{g})$ & $K_{1}\left(\mathrm{~h}^{-1}\right)$ & $R^{2}$ & $q_{e 2, \text { cal }}(\mathrm{mg} / \mathrm{g})$ & $K_{2}(\mathrm{~g} / \mathrm{mgh})$ & $R^{2}$ & $\mathrm{Rate}$ \\
\hline 200 & 98.288 & 27.7332 & 0.0092 & 0.875 & 100.000 & 0.00088 & 0.999 & 0.088417 \\
300 & 147.792 & 59.8136 & 0.0083 & 0.927 & 151.515 & 0.00037 & 0.999 & 0.055462 \\
400 & 165.826 & 46.4943 & 0.0044 & 0.873 & 166.667 & 0.00046 & 0.999 & 0.076336 \\
\hline
\end{tabular}


TABLE 4: Constants of the intraparticle diffusion model for $\mathrm{MnO}_{4}{ }^{-}$sorption by $\mathrm{ZCOBLP}$.

\begin{tabular}{lcccrrr}
\hline \multirow{2}{*}{$C_{0}(\mathrm{mg} / \mathrm{L})$} & \multicolumn{3}{c}{ Region I } & \multicolumn{3}{c}{ Region II } \\
& $K_{\text {dif }}\left(\mathrm{mg} / \mathrm{h}^{1 / 2} \mathrm{~g}\right)$ & $C$ & $R^{2}$ & $K_{\mathrm{dif}}\left(\mathrm{mg} / \mathrm{h}^{1 / 2} \mathrm{~g}\right)$ & 0.0182 & $R^{2}$ \\
\hline 200 & 3.8481 & 44.782 & 0.812 & 0.1001 & 0.772 \\
300 & 6.098 & 54.033 & 0.881 & 0.4913 & 144.780 \\
400 & 7.1288 & 69.870 & 0.857 & 150.030 & 0.922 \\
\hline
\end{tabular}

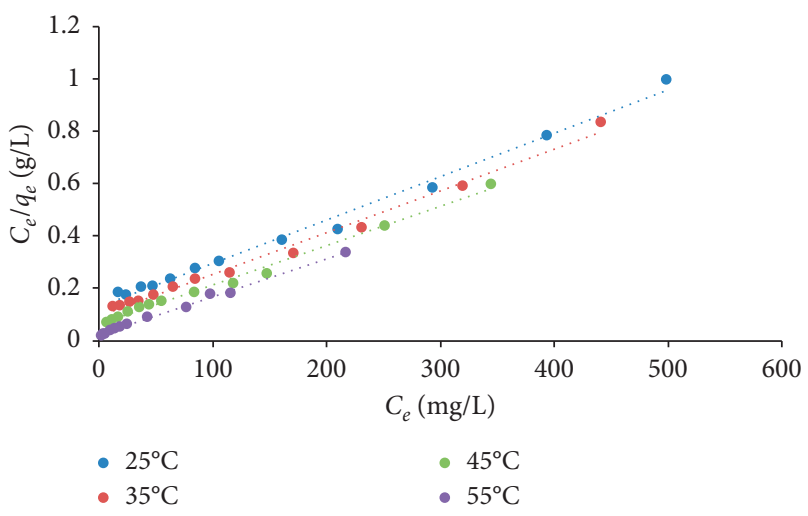

FIgURE 8: Langmuir isotherm for $\mathrm{MnO}_{4}^{-}$ions sorption by ZCOBLP.

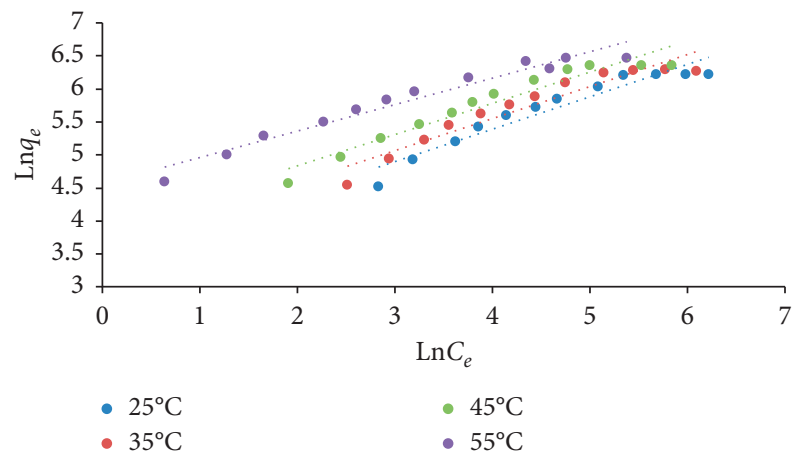

FIGURE 9: Freundlich isotherm for $\mathrm{MnO}_{4}{ }^{-}$ions sorption by ZCOBLP.

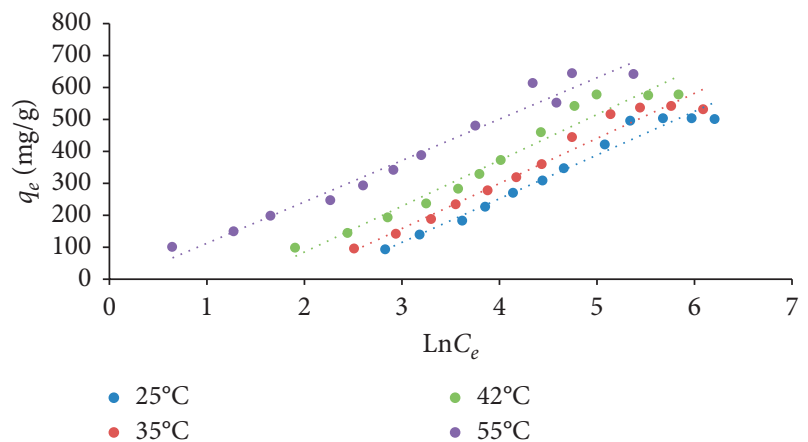

FIgURE 10: Temkin isotherm for $\mathrm{MnO}_{4}{ }^{-}$ions sorption by ZCOBLP. study. Similar trends were noticed in the case $\mathrm{MnO}_{4}{ }^{-}$ions sorption by Nitraria retusa leaves powder [32], neem leaves powder [33], and another low-cost sorbent [40].

It can also be seen from Table 5 that the sorbent prepared and used in this study has superior sorption capacities towards $\mathrm{MnO}_{4}{ }^{-}$ions; this confirms that this low-cost, higheffective sorbent will receive more attention in the purification of water and wastewater from $\mathrm{MnO}_{4}{ }^{-}$ions.

Additionally, these capacities increased from $588.235 \mathrm{mg} \cdot \mathrm{g}^{-1}$ to $714.286 \mathrm{mg} \cdot \mathrm{g}^{-1}$ when temperature elevated from $25^{\circ} \mathrm{C}$ to $55^{\circ} \mathrm{C}$, confirming the endothermic sorption as mentioned in Section 3.2.3.

3.5. Thermodynamic Constants. The thermodynamic constants of this sorption were evaluated from slopes and intercepts of the plots shown in Figure 11 and documented in Table 6. It can be noted that the $\Delta H^{\circ}$ and $\Delta S^{\circ}$ values are positive (Table 6), confirming an endothermic sorption and decreasing the randomness due to occurrence of the sorption process [41]. Additionally, all $\Delta H^{\circ}$ values (Table 6) are higher than $20.9 \mathrm{~kJ} / \mathrm{mol}$, which confirms the chemisorption process [25]. These outcomes are totally similar to those results previous observed by Al-Aoh and Bani-Atta [17, 40].

Moreover, the positive values of $\Delta S^{\circ}$ are decreased with increasing the concentration of $\mathrm{MnO}_{4}{ }^{-}$in the solution, evidencing that the concentration of $\mathrm{MnO}_{4}{ }^{-}$ions is the most effective variable in this sorption.

The negative values of $\Delta G^{\circ}$ (Table 6) indicate the spontaneity of this sorption. The similar outcomes were reported for sorption of $\mathrm{MnO}_{4}{ }^{-}$ions by sage leaves powder [40] and neem leaves powder [33].

Furthermore, there is an accordance between the outcomes of thermodynamic and kinetic studies, where both of them confirm that the ions of $\mathrm{MnO}_{4}{ }^{-}$were chemically adsorbed on the surface of ZCOBLP.

\section{Comparison Study}

For comparison, the sorption capacities of the sorbent (ZCOBLP) used in this research towards $\mathrm{MnO}_{4}{ }^{-}$anions and capacities of some selected sorbent earlier used for sorption of $\mathrm{MnO}_{4}{ }^{-}$anions from liquid phases are documented in Table 7. The ZCOBLP has higher sorption capabilities than Nitraria retusa leaves powder, modified carbonaceous 
TABLE 5: Constants of isotherms for $\mathrm{MnO}_{4}{ }^{-}$sorption via ZCOBLP.

\begin{tabular}{|c|c|c|c|c|c|c|c|c|c|c|c|}
\hline \multirow{2}{*}{ Temperature } & \multicolumn{4}{|c|}{ Langmuir isotherm } & \multicolumn{4}{|c|}{ Freundlich isotherm } & \multicolumn{3}{|c|}{ Temkin isotherm } \\
\hline & $q_{\max }\left(\mathrm{mg} \cdot \mathrm{g}^{-1}\right)$ & $K_{L}\left(\mathrm{~L} \cdot \mathrm{mg}^{-1}\right)$ & $R_{L}$ & $R^{2}$ & $K_{F}(\mathrm{mg} / \mathrm{g})\left(\mathrm{L} \cdot \mathrm{mg}^{-1}\right) 1 / n$ & $1 / n$ & $n$ & $R^{2}$ & $K_{T}\left(\mathrm{~L} \cdot \mathrm{mg}^{-1}\right)$ & $B_{1}$ & $R^{2}$ \\
\hline $25^{\circ} \mathrm{C}$ & 588.235 & 0.0131 & 0.07084 & 0.991 & 30.3258 & 0.494 & 2.024 & 0.921 & 0.11630 & 136.27 & 0.968 \\
\hline $35^{\circ} \mathrm{C}$ & 5.000 & 170 & 0.05566 & 0.992 & 36.9328 & 0.487 & 2.055 & 0.919 & 0.15468 & 140.72 & 0.966 \\
\hline $45^{\circ} \mathrm{C}$ & 666.667 & 0.0245 & 0.03926 & 0.992 & 48.8962 & 0.473 & 2.114 & 0.936 & 0.24583 & 143.14 & 0.959 \\
\hline $55^{\circ} \mathrm{C}$ & 714.286 & 0.0609 & 0.01616 & 0.993 & 95.0402 & 0.402 & 2.488 & 0.956 & 0.87798 & 129.41 & 0.972 \\
\hline
\end{tabular}

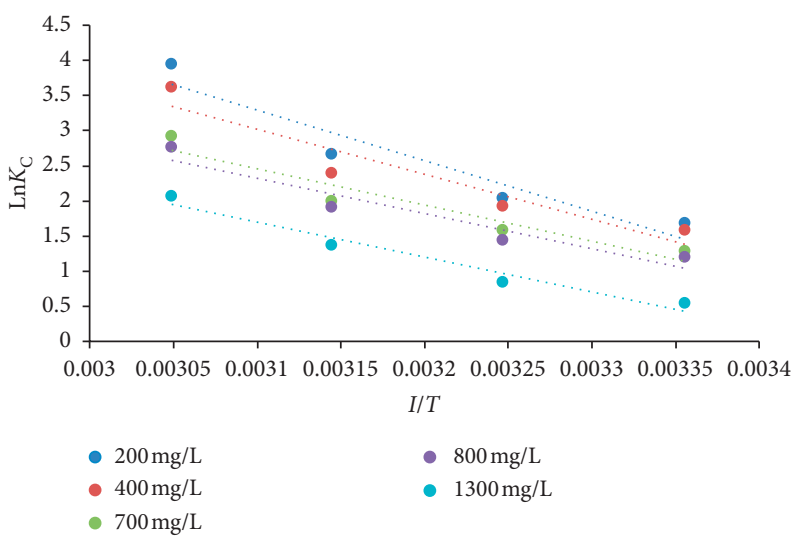

FIgURE 11: Thermodynamic parameters for $\mathrm{MnO}_{4}{ }^{-}$ions sorption by ZCOBLP.

TABLE 6: Thermodynamic constants for $\mathrm{MnO}_{4}{ }^{-}$sorption by ZCOBLP.

\begin{tabular}{|c|c|c|c|c|c|c|c|}
\hline \multirow{2}{*}{ Initial concentration $\left(\mathrm{mg} \cdot \mathrm{L}^{-1}\right)$} & \multirow{2}{*}{$\Delta H^{\circ}\left(\mathrm{kJ} \cdot \mathrm{Mol}^{-1}\right)$} & \multirow{2}{*}{$\Delta S^{\circ}\left(\mathrm{kJ} \cdot \mathrm{Mol}^{-1}\right)$} & \multicolumn{4}{|c|}{$\Delta G^{\circ}\left(\mathrm{kJ} \cdot \mathrm{Mol}^{-1}\right)$} & \multirow{2}{*}{$R^{2}$} \\
\hline & & & $298 \mathrm{~K}$ & $308 \mathrm{~K}$ & $318 \mathrm{~K}$ & $328 \mathrm{~K}$ & \\
\hline 200 & 59.88159 & 0.21303 & -3.60124 & -5.73154 & -7.86183 & -9.99213 & 0.908 \\
\hline 400 & 53.30687 & 0.190332 & -3.41218 & -5.31551 & -7.21883 & -9.12215 & 0.895 \\
\hline 700 & 42.76638 & 0.152994 & -2.8259 & -4.35584 & -5.88578 & -7.41572 & 0.917 \\
\hline 800 & 41.66561 & 0.148446 & -2.57144 & -4.0559 & -5.54037 & -7.02483 & 0.920 \\
\hline 1300 & 41.23993 & 0.141912 & -1.04974 & -2.46886 & -3.88798 & -5.30709 & 0.957 \\
\hline
\end{tabular}

TABLE 7: $\mathrm{MnO}_{4}^{-}$ion sorption capacities on ZCOBLP and other sorbents.

\begin{tabular}{|c|c|c|c|}
\hline Sorbents & \multicolumn{2}{|c|}{$q_{\max }\left(\mathrm{mg} \cdot \mathrm{g}^{-1}\right)$} & Sources \\
\hline \multirow{4}{*}{ Zinc chloride Ocimum basilicum leaves powder } & 588.235 & $25^{\circ} \mathrm{C}$ & \multirow{4}{*}{ This work } \\
\hline & 625.000 & $35^{\circ} \mathrm{C}$ & \\
\hline & 666.667 & $45^{\circ} \mathrm{C}$ & \\
\hline & 714.286 & $55^{\circ} \mathrm{C}$ & \\
\hline \multirow{3}{*}{ Nitraria retusa leaves powder } & 312.50 & $30^{\circ} \mathrm{C}$ & \multirow{3}{*}[33]{} \\
\hline & 333.33 & $50^{\circ} \mathrm{C}$ & \\
\hline & 344.83 & $60^{\circ} \mathrm{C}$ & \\
\hline Activated charcoal & \multicolumn{2}{|c|}{57.47} & {$[11]$} \\
\hline Animal bone-derived activated carbon & \multicolumn{2}{|c|}{28.04} & {$[14]$} \\
\hline Activated carbon derived from corncob & \multicolumn{2}{|c|}{26.00} & {$[14]$} \\
\hline Coconut shells-derived activated carbon & \multicolumn{2}{|c|}{23.25} & {$[15]$} \\
\hline Modified carbonaceous materials & \multicolumn{2}{|c|}{$100.00 \pm 0.5 \%$} & [16] \\
\hline
\end{tabular}

materials, activated charcoal, and activated carbon generated from animal bone, carbon corncob, and coconut shells, as demonstrated in Table 7.

\section{Conclusions}

In this research, the characterization of zinc chloride Ocimum basilicum leaves powder (ZCOBLP) and its efficiency for sorption of $\mathrm{MnO}_{4}{ }^{-}$at various operative conditions were studied. Characterization results exhibited that ZCOBLP has five functional groups on its surface, $\mathrm{pH}_{\mathrm{ZPC}}=8.3$ and surface area $=117.27 \mathrm{~m}^{2} \cdot \mathrm{g}^{-1}$. The dynamic constants of this sorption were determined using first- and second-order dynamic models, as well as the equation of intraparticle diffusion.

The equilibrium results of this sorption were analyzed by models of Temkin, Freundlich, and Langmuir. The results of 
sorption experiments approve that concentration of $\mathrm{MnO}_{4}{ }^{-}$, temperature, and time of contact have positive influences on this sorption, while $\mathrm{pH}$ has a negative influence. The achieved dynamic constants confirm that 2 nd-order dynamic model was the best model that can be applied for this sorption. The equilibrium results show that $\mathrm{MnO}_{4}{ }^{-}$sorption by ZCOBLP is a spontaneous and heat-absorbing process, with the Langmuir model being the optimal isotherm model to use. The sorption capacities got in this work were 588.235, $625.000,666.667$, and $714.286 \mathrm{mg} \cdot \mathrm{g}^{-1}$ at $25,35,45$, and $55^{\circ} \mathrm{C}$, correspondingly. ZCOBLP will be successfully employed for decontamination of chemically polluted wastewaters due to its inexpensive price and availability, as well as its sufficient sorption capability for $\mathrm{MnO}_{4}{ }^{-}$.

\section{Data Availability}

No data were used to support this study.

\section{Conflicts of Interest}

The authors declare that they have no conflicts of interest regarding the publication of this paper.

\section{Acknowledgments}

The authors are grateful to the Faculty of Science at the University of Tabuk for their ongoing support and facilities in completing this project.

\section{References}

[1] M. C. Stuart, M. Kouimtzi, and S. R. Hill, WHO Model Formulary 2008, pp. 295-300, World Health Organization, Geneva, Switzerland, 2009.

[2] World Health Organization, World Health Organization Model List of Essential Medicines: 21st List 2019, World Health Organization, Geneva, Switzerland, 2019.

[3] A. Ahmad, E. Cornelissen, S. van de Wetering et al., "Arsenite removal in groundwater treatment plants by sequential permanganate ferric treatment," Journal of Water Process Engineering, vol. 26, pp. 221-229, 2018.

[4] M. Elsheikh, H. Guirguis, and A. Fathy, "Removal of iron and manganese from groundwater: a study of using potassium permanganate and sedimentation," MATEC Web of Conferences, vol. 162, p. 05018, 2018.

[5] Assembly of Life Sciences (US), "Safe drinking water committee," Drinking Water and Health, National Academies Press, vol. 2, p. 98, Washington, DC, USA, 1977.

[6] D. He, X. Guan, J. Ma, X. Yang, and C. Cui, "Influence of humic acids of different origins on oxidation of phenol and chlorophenols by permanganate," Journal of Hazardous Materials, vol. 182, no. 1-3, pp. 681-688, 2010.

[7] J. Jiang, S.-Y. Pang, and J. Ma, "Oxidation of triclosan by permanganate $(\mathrm{Mn}(\mathrm{VII}))$ : importance of ligands and in situ formed manganese oxides," Environmental Science \& Technology, vol. 43, no. 21, pp. 8326-8331, 2009.

[8] C. Liu, L. Zhang, F. Li et al., "Dependence of sulfadiazine oxidative degradation on physicochemical properties of manganese dioxides," Industrial \& Engineering Chemistry Research, vol. 48, no. 23, pp. 10408-10413, 2009.
[9] C. Kao, K. Huang, J. Wang, T. Chen, and H. Chien, “Application of potassium permanganate as an oxidant for in situ oxidation of trichloroethylene-contaminated groundwater: a laboratory and kinetics study," Journal of Hazardous Materials, vol. 153, no. 3, pp. 919-927, 2008.

[10] E. Rodríguez, G. D. Onstad, T. P. J. Kull, J. S. Metcalf, J. L. Acero, and U. von Gunten, "Oxidative elimination of cyanotoxins: comparison of ozone, chlorine, chlorine dioxide and permanganate," Water Research, vol. 41, no. 15, pp. 3381-3393, 2007.

[11] R. K. Verma, R. Kapoor, S. K. Gupta, and R. R. Chaudhari, "An efficient technique for removal of $\mathrm{K}^{+}$and $\mathrm{MnO}_{4}{ }^{-}$ions through adsorption in aqueous solution by using activated charcoal," Pharmaceutical Chemistry Journal, vol. 1, pp. 20$25,2014$.

[12] Z. Abdeen, S. G. Mohammad, and M. S. Mahmoud, “Adsorption of $\mathrm{Mn}$ (II) ion on polyvinyl alcohol/chitosan dry blending from aqueous solution," Environmental Nanotechnology, Monitoring \& Management, vol. 3, pp. 1-9, 2015.

[13] G.-X. Li, Y.-H. Huaug, T.-C. Chen, Y.-J. Shih, and H. Zhang, "Reduction and immobilization of potassium permanganate on iron oxide catalyst by fluidized-bed crystallization technology," Applied Sciences, vol. 2, no. 1, pp. 166-174, 2012.

[14] D. J. Ezeugo and C. V. Anadebe, "Removal of potassium permanganate from aqueous solution by adsorption onto activated carbon prepared from animal bone and corn cob," Equatorial Journal of Engineering, vol. 2018, p. 21, 2018.

[15] F. Aprilliani, E. Warsiki, and A. Iskandar, "Kinetic studies of potassium permanganate adsorption by activated carbon and its ability as ethylene oxidation material," IOP Conference Series: Earth and Environmental Science, vol. 141, p. 012003, 2018.

[16] M. E. Mahmoud, A. A. Yakout, S. R. Saad, and M. M. Osman, "Removal of potassium permanganate from water by modified carbonaceous materials," Desalination and Water Treatment, vol. 57, no. 33, pp. 15559-15569, 2016.

[17] H. A. Al-Aoh, I. A. Mihaina, M. A. Alsharif et al., "Removal of methylene blue from synthetic wastewater by the selected metallic oxides nanoparticles adsorbent: equilibrium, kinetic and thermodynamic studies," Chemical Engineering Communications, vol. 207, pp. 1-17, 2019.

[18] S. Rani, M. Aggarwal, M. Kumar, S. Sharma, and D. Kumar, "Removal of methylene blue and rhodamine B from water by zirconium oxide/graphene," Water Science, vol. 30, no. 1, pp. 51-60, 2016.

[19] H. Tavakkoli and F. Hamedi, "Synthesis of $\mathrm{Gd}_{0.5} \mathrm{Sr}_{0.5} \mathrm{FeO}_{3}$ perovskite-type nanopowders for adsorptive removal of $\mathrm{MB}$ dye from water," Research on Chemical Intermediates, vol. 42, no. 4, pp. 3005-3027, 2016.

[20] L. Y. Chin, L. Y. Pei, R. B. Rosli, and N. H. B. Mohd Atni, "Immobilization of nano-sized $\mathrm{TiO}_{2}$ on glass plate for the removal of methyl orange and methylene blue," in ICGSCE 2014, pp. 105-113, Springer, Singapore, 2015.

[21] G. Mustafa, H. Tahir, M. Sultan, and N. Akhtar, "Synthesis and characterization of cupric oxide $(\mathrm{CuO})$ nanoparticles and their application for the removal of dyes," African Journal of Biotechnology, vol. 12, pp. 6650-6660, 2013.

[22] S.-T. Yang, S. Chen, Y. Chang, A. Cao, Y. Liu, and H. Wang, "Removal of methylene blue from aqueous solution by graphene oxide," Journal of Colloid and Interface Science, vol. 359, no. 1, pp. 24-29, 2011.

[23] F. Li, X. Wu, S. Ma, Z. Xu, W. Liu, and F. Liu, "Adsorption and desorption mechanisms of methylene blue removal with iron- 
oxide coated porous ceramic filter," Journal of Water Resource and Protection, vol. 1, pp. 1-57, 2009.

[24] M. Özkan, "Glandular and eglandular hairs of Salvia recognita Fisch. \& Mey.(Lamiaceae) in Turkey Bangladesh," Journal of Botany, vol. 37, pp. 93-95, 2008.

[25] S. K. Theydan and M. J. Ahmed, "Adsorption of methylene blue onto biomass-based activated carbon by $\mathrm{FeCl}_{3}$ activation: equilibrium, kinetics, and thermodynamic studies," Journal of Analytical and Applied Pyrolysis, vol. 97, pp. 116-122, 2012.

[26] H. A. Said-Al Ahl, A. M. Sarhan, A. D. M. A. Dahab et al., "Essential oils of Anethum graveolens L.: chemical composition and their antimicrobial activities at vegetative, flowering and fruiting stages of development," International Journal of Plants Sciences, vol. 1, pp. 98-102, 2015.

[27] T. Gallardo-Velázquez, G. Osorio-Revilla, M. Z.-D. Loa, and Y. Rivera-Espinoza, "Application of FTIR-HATR spectroscopy and multivariate analysis to the quantification of adulterants in Mexican honeys," Food Research International, vol. 42, no. 3, pp. 313-318, 2009.

[28] N. Subari, J. Mohamad Saleh, A. Md Shakaff, and A. Zakaria, "A hybrid sensing approach for pure and adulterated honey classification," Sensors, vol. 12, no. 10, pp. 14022-14040, 2012.

[29] X.-L. Wu, Y. Shi, S. Zhong, H. Lin, and J.-R. Chen, "Facile synthesis of $\mathrm{Fe}_{3} \mathrm{O}_{4}$-graphene@mesoporous $\mathrm{SiO}_{2}$ nanocomposites for efficient removal of methylene blue," Applied Surface Science, vol. 378, pp. 80-86, 2016.

[30] B. Qu, J. Zhou, X. Xiang, C. Zheng, H. Zhao, and X. Zhou, "Adsorption behavior of azo dye C. I. acid red 14 in aqueous solution on surface soils," Journal of Environmental Sciences (China), vol. 20, pp. 704-709, 2008.

[31] V. K. Gupta, B. Gupta, A. Rastogi, S. Agarwal, and A. Nayak, "A comparative investigation on adsorption performances of mesoporous activated carbon prepared from waste rubber tire and activated carbon for a hazardous azo dye-acid blue 113," Journal of Hazardous Materials, vol. 186, no. 1, pp. 891-901, 2011.

[32] H. A. AL-Aoh, "Adsorption of $\mathrm{MnO}_{4}{ }^{-}$from aqueous solution by Nitraria retusa leaves powder; kinetic, equilibrium and thermodynamic studies," Materials Research Express, vol. 6, p. 115102, 2019.

[33] H. A. AL-Aoh, "Equilibrium, thermodynamic and kinetic study for potassium permanganate adsorption by neem leaves powder," Desalination and Water Treatment, vol. 170, pp. 101-110, 2019.

[34] I. Kaya, N. Yigit, and M. Benli, "Antimicrobial activity of various extracts of Ocimum basilicum L. and observation of the inhibition effect on bacterial cells by use of scanning electron microscopy," African Journal of Traditional, Complementary and Alternative Medicines, vol. 5, no. 4, pp. 363-369, 2008.

[35] A. Gupte, M. Karjikar, and J. Nair, "Biosorption of copper using mucilaginous seeds of Ocimum basilicum," Acta Biologica Indica, vol. 1, pp. 113-119, 2012.

[36] D. Chakraborty, S. Maji, A. Bandyopadhyay, and S. Basu, "Biosorption of cesium-137 and strontium-90 by mucilaginous seeds of Ocimum basilicum," Bioresource Technology, vol. 98, no. 15, pp. 2949-2952, 2007.

[37] J. S. Melo and S. F. D’Souza, "Removal of chromium by mucilaginous seeds of Ocimum basilicum," Bioresource Technology, vol. 92, no. 2, pp. 151-155, 2004.

[38] S. Shamsnejati, N. Chaibakhsh, A. R. Pendashteh, and S. Hayeripour, "Mucilaginous seed of Ocimum basilicum as a natural coagulant for textile wastewater treatment," Industrial Crops and Products, vol. 69, pp. 40-47, 2015.
[39] B. H. Hameed and A. A. Ahmad, "Batch adsorption of Methylene blue from aqueous solution by garlic peel, an agricultural waste biomass," Journal of Hazardous Materials, vol. 164, no. 2-3, pp. 870-875, 2009.

[40] S. A. Bani-Atta, "Zinc chloride modification of sage leaves powder and its application as an adsorbent for $\mathrm{KMnO}_{4}$ removal from aqueous solutions," Materials Research Express, vol. 7, p. 095511, 2020.

[41] M. Cegłowski and G. Schroeder, "Removal of heavy metal ions with the use of chelating polymers obtained by grafting pyridine-pyrazole ligands onto polymethylhydrosiloxane," Chemical Engineering Transactions, vol. 259, pp. 885-893, 2015. 